\title{
GENERAAL JOAQUIM JOSE MACHADO, DIE MAN NA WIE MACHADODORP VERNOEM IS
}

Prof O.J.O. Ferreira*

\begin{abstract}
Hierdie artikel deur Prof O.J.O. Ferreira, verbonde aan die Dept Afrikaanse en Nederlandse Kultuurgeskiedenis van die Universiteit van Pretoria, handel oor die lewe en loopbaan van die merkwaardige generaal Joaquim Jose Machado, 'n man wie se naam altyd onafskeidbaar verbonde sal bly aan die spoorwegontwikkeling in suidelike Afrika.
\end{abstract}

Volgens 'n Goewermentstransport het die plaas Geluk in die distrik Lydenburg op 6 April 1864 die eiendom van Cornelis Potgieter, die tweede landdros van die Republiek Lydenburg, geword. Nadat goud in Oos-Transvaal ontdek is, het hierdie plaas, vanweë sy gunstige ligging, spoedig 'n erkende uitspanplek vir transportwaens en poskoetse geword. Die vroeë geskiedenis van die plaas Geluk en die dorp wat daarop uitgemeet sou word, is dan ook baie nou verbonde aan die poskoetsroetes en die spoorlyn wat vanaf Lourenço Marques na Pretoria aangelê is. In 1893 is 'n stasie langs hierdie Oosterlyn op die plaas Geluk opgerig en die volgende jaar het landmeter H.U. von Quintzow die dorpsgebied daaromheen uitgemeet. ' $n$ Kaart van die dorp is in Mei 1899 geregistreer, maar die nuwe aanleg is eers op 12 Desember 1904 tot dorp geproklameer. ${ }^{1}$

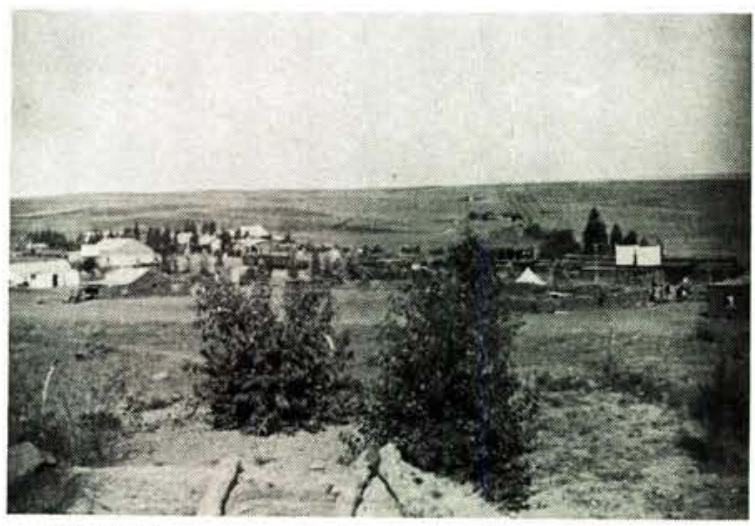

Machadodorp aan die begin van die twintigste eeu. (Foto: Transvaalse Argiefbewaarplek, Pretoria)

Die dorp en stasie wat op die plaas Geluk aangelê is, dra die naam Machadodorp, 'n naam wat ietwat vreemd op die Afrikaner se oor en oog val en deur die Boere dikwels as Makadodorp uitgespreek is en deur heelwat van die jonger geslag met die naam van een of ander Swart leier uit die Transvaalse verlede geassosieer word. In die geskiedenis van die Zuid-Afrikaansche Republiek het hierdie beskeie dorpie 'n belangrike rol gespeel. Dit was naamlik op
Machadodorp waar staatspresident S.J.P. Kruger op 30 Mei 1900 aangekom en vir 'n maand in sy spoorwegwa gewoon het en waarheen die regeringsetel van die Z.A.R. op 5 Junie 1900 tydelik verskuif is nadat Pretoria deur die Britse troepe ingeneem is. Die koue van Machadodorp het Kruger egter op 30 Junie 1900, af in die Laeveld na Waterval-Onder gedryf, waar die milde klimaat en skoonheid van die Elandsrivier vir die grysaard lafenis gebring het. Die setel van die regering het egter op Machadodorp gebly, waarvandaan die Staatsekretaris en lede van die Uitvoerende Raad elke dag per trein na Waterval-Onder gereis het om regeringsake met die President te bespreek. Eers nadat generaal Redvers Buller Machadodorp op 28 Augustus 1900 beset het, het die regeringsetel van die Z.A.R. na Nelspruit verskuif. ${ }^{2}$

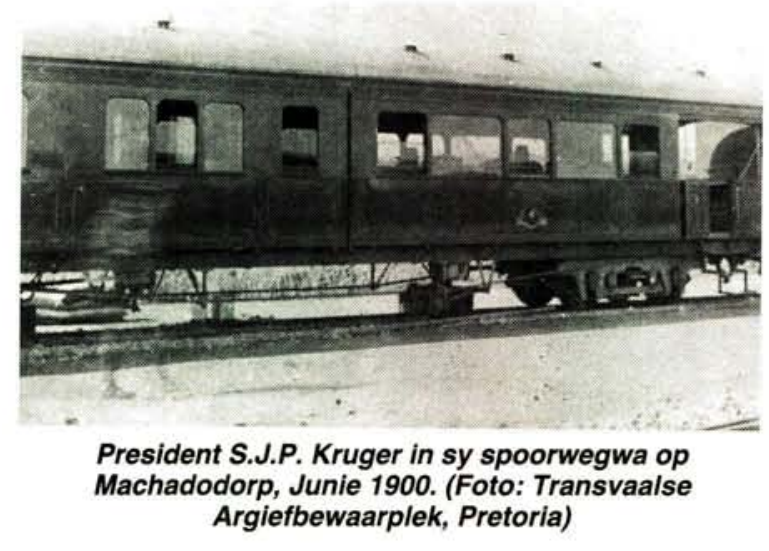

Maar vanwaar die vreemdsoortige naam van hierdie tydelike regeringsetel van die Z.A.R.? Die verhaal van die naamgewing begin by die geboorte van Joaquim José Machado op 24 September 1847 in die eenvoudige en selfs armoedige huisie van Francisco José Machado en sy vrou, Maria da Gloria, in Lagos, 'n hawestad in die suide van Portugal. Lagos was reeds tydens die groot ontdekkingsreise van die Portugese in die vyftiende eeu 'n belangrike hawe; trouens, dit was die basis waarvandaan die ekspedisies in die tyd van Prins Hendrik die 
Seevaarder onderneem is. 'n Standbeeld van die Prins is dan ook heel gepas in 1960 op 'n groot plein tussen die ou stad en die hawe opgerig, terwyl die Santa Maria Kerk, waarin Prins Hendrik aanvanklik begraaf is, en die gebou waar die eerste slawe uit Afrika verkoop is aan weerskante van hierdie plein staan. ${ }^{3}$

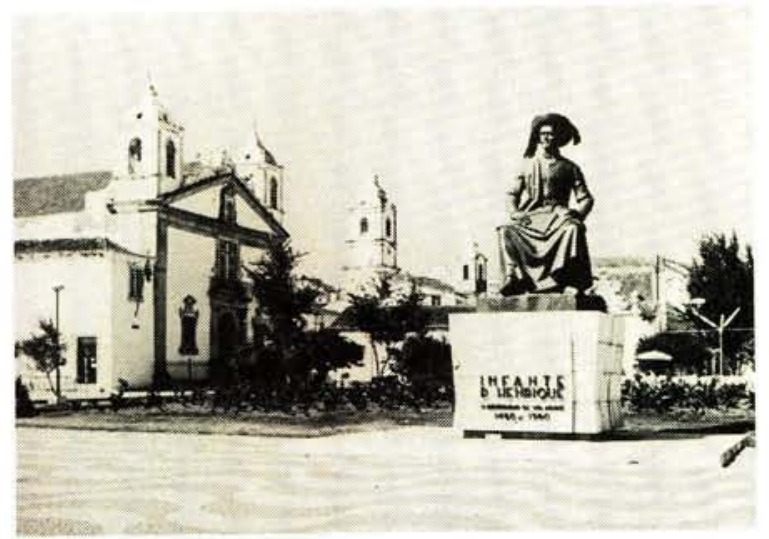

Standbeeld van Prins Hendrik die Seevaarder op die plein van Lagos, geboorteplek van Machado. (Uit: C.V. da S. Barros, Portugal (Lissabon, 1978), p. 141)

Ten spyte van die feit dat sy ouers baie arm was en hy vyf broers en een suster gehad het, het Machado se leergierigheid hom daartoe gedryf om ingenieurswese en landmeetkunde aan die Politegniese Skool in Lissabon te gaan studeer. Hy het besonder goed presteer en om sy studiegeld te kon betaal, het hy reeds as student aan sy medestudente private klasse gegee.4

Machado het reeds van jongs af ' $n$ belangstelling in militêre sake gehad en op 21 Oktober 1869 het hy dus as vrywilliger by die 10de Infanterie Regiment aangesluit. In 1873 het hy sy opleiding as genie-offisier aan die Krygskool in Lissabon voltooi en is daarna by die ingenieursafdeling van die leër ingedeel. Bevordering het snel daarna gevolg: op 9 Desember 1873 is hy tot tweede luitenant en op 1 Augustus 1876 tot kaptein bevorder. ${ }^{5}$

Die tyd was gunstig vir sy loopbaan. Die Portugese Minister van die Vloot, João de Andrade Corvo, het in 1876 'n ontwikkelingsplan vir Angola en Mosambiek opgestel. Machado het homself bereidwillig verklaar om in die oorsese gebiede diens te gaan doen, waarop Corvo besluit het om hom as hoof van Openbare Werke na Mosambiek te stuur. Die bekwame wyse waarop Machado die beplanning en voorbereidings vir hierdie projek in Portugal gedoen het, het daartoe aanleiding gegee dat hy reeds voor sy vertrek na Mosambiek op 13 September 1876 tot majoor bevorder is. Om destyds in Portugal op die jeugdige ouderdom van 29 jaar tot 'n majoor bevorder te word, was 'n uitsonderlike prestasie. $^{6}$

Een van die ondernemings wat Machado met groot geesdrif in Mosambiek aangepak het, was die opmeting van die trajek vir die spoorlyn van Lourenço Marques na die grens van die Z.A.R. om sodoende die handelsverkeer met die Transvaal te verhoog. Die konsessie vir die bou van die spoorlyn is aanvanklik aan ' $n$ Amerikaanse finansier, Eduard McMurdo, toegeken, maar na drie jaar het hy die konsessie aan 'n internasionale maatskappy, die Delagoa Bay and East African Company, verkoop. Teen Desember 1887 was die bou van die spoorlyn tot aan die Transvaalse grens voltooi, maar toe ontdek Machado dat die grens as gevolg van 'n opmeetfout nog tien kilometer verder wes was. Dit het 'n dispuut tussen die Portugese owerheid en die Delagoa Bay and East African Company laat ontstaan, wat daartoe gelei het dat die Portugese regering in 1889 op die spoorlyn beslag gelê het omdat dit nie binne die bestemde tyd voltooi is nie. Op 15 Maart 1890 het die Portugese regering Machado as hulle verteenwoordiger by die vasstelling van die grens tussen Mosambiek en Transvaal aangewys. Na arbitrasie het die maatskappy $£ 1$ miljoen as kompensasie ontvang en is die spoorlyn tot aan die Transvaalse grens voltooi. ${ }^{7}$

Reeds aan die begin van 1883 het Machado Pretoria besoek om die aanlê van die spoorweg na Delagoabaai met lede van die regering van die Z.A.R. te bespreek en sy opnames vir die Mosambiekse gedeelte van hierdie spoorlyn aan hulle te toon. Machado het soveel vertroue by hulle ingeboesem dat die Transvaalse regering besluit het om die Portugese owerheid te vra om Machado se dienste tot hulle beskikking te stel vir die opmeting van die spoorlyn van die Mosambiekse grens tot in Pretoria. Die Portugese regering het toegestem en die Volksraad van die Z.A.R. het $£ 4000$ tot die beskikking van Machado vir hierdie projek gestel. Teen die einde van 1883 het Machado met die hulp van slegs drie blanke assistente ' $n$ aanvang gemaak om die spoorlyn op te meet en die opname binne agt maande voltooi. Dit was 'n uiters moeilike taak, want tussen die Laeveld en die Hoëveld staan die haas ondeurdringbare berge van die Platorand. Machado het hom skitterend van sy taak gekwyt en die plan wat hy opgestel het, was - hoewel in sekere onderdele gewysig steeds die basis waarvolgens die Neder- 
landsch-Zuid-Afrikaansche Spoorweg Maatschappij die Transvaalse gedeelte van die Oosterlyn aangelê het. Tydens die feestelike opening van hierdie spoorlyn in Julie 1895 het Machado die verrigtinge as amptelike verteenwoordiger van die Portugese regering bygewoon. ${ }^{8}$

In 1886 het die Portugese regering Machado aangestel om die Ambaca-spoorlyn te bestuur, terwyl hy in 1888 'n opname vir die aanlê van die Mossamedes-spoorlyn in Angola gedoen het. Hy was ook 'n tyd lank die administrateur van die spoorwegmaatskappy, die Companhia dos Caminhos de Ferro de Benguela. Intussen het sy militêre bevordering nie agterweë gebly nie. Hy is reeds op 27 Julie 1887 tot luitenant-kolonel en op 21 November 1895 tot kolonel bevorder. ${ }^{9}$

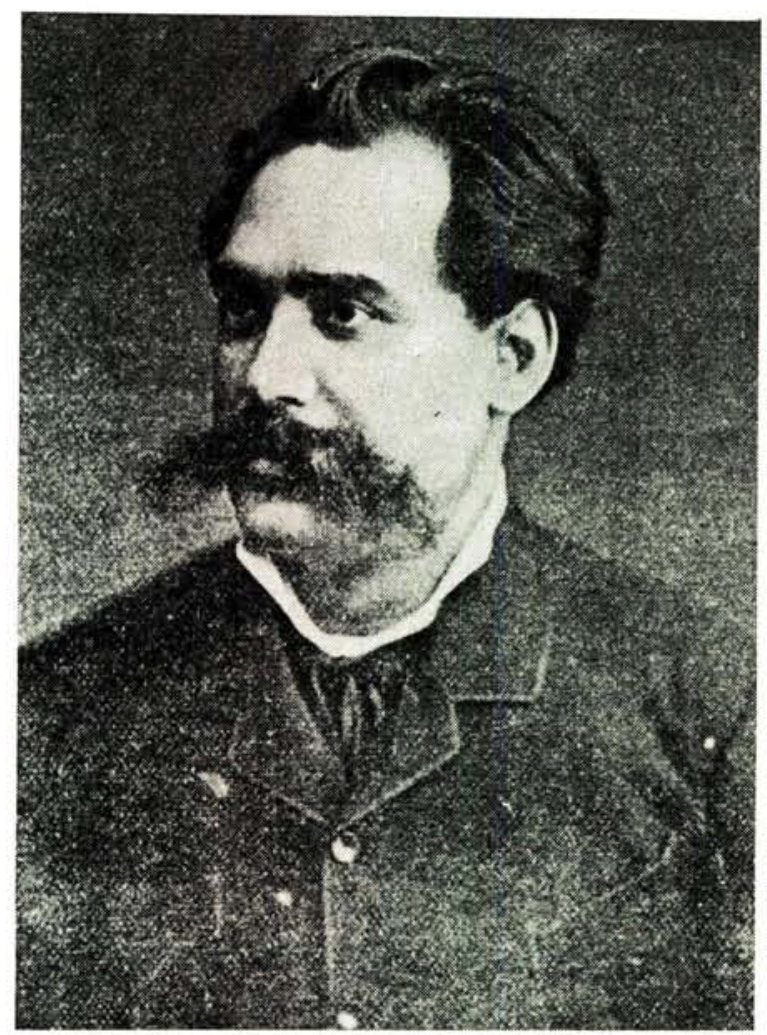

Kolonel Joaquim José Machado. (Foto: Transvaalse Argiefbewaarplek, Pretoria)

In November 1889 het Machado 'n vergadering van die Sociedade de Geografia in Lissabon toegespreek en voorgestel dat verkeersweë tussen Mosambiek en die aangrensende gebiede verder uitgebrei moet word en dat Portugese kolonisasie daarop kon volg. Aangesien hy die gebied teen hierdie tyd goed geken het, is dit nie vreemd dat hy op 29 Desember 1889 as goewerneur-generaal van Mosambiek aangestel is nie. Hy het die amp op 20 Januarie 1890 aanvaar. Die volgende jaar is hy ook tot hoof van die Companhia de Moçambique, 'n maatskappy wat Mosambiek ekonomies moes ontwikkel, benoem. ' $n$ Verdere onderskeiding het Machado te beurt geval toe hy op 17 Mei 1897 ook as goewerneur-generaal van die klein Portugese gebied in Voor-Indië, Goa, aangestel is. Hy het hierdie benoeming van die hand gewys. ${ }^{10}$

As goewerneur-generaal van Mosambiek was Machado in September-Oktober 1900 die gasheer van staatspresident S.J.P. Kruger in Lourenço Marques voordat die President as balling na Europa vertrek het. Machado het die President reeds die tweede dag na sy aankoms verplig om sy intrek in die goewerneurswoning te neem. Daar was hy feitlik 'n gevangene sonder verbinding met sy eie mense en Machado het hom meegedeel dat hy toegelaat sou word om te vertrek slegs as sy bestemming Europa is. Hierdie optrede van die Portugese owerheid het ongetwyfeld onder druk van die Engelse regering plaasgevind. Machado se opdrag het hom stellig geen vreugde verskaf nie en hy het die President en sy geselskap baie vriendelik behandel totdat hulle op 20 Oktober 1900 aan boord van die Gelderland na Europa vertrek het. ${ }^{11}$

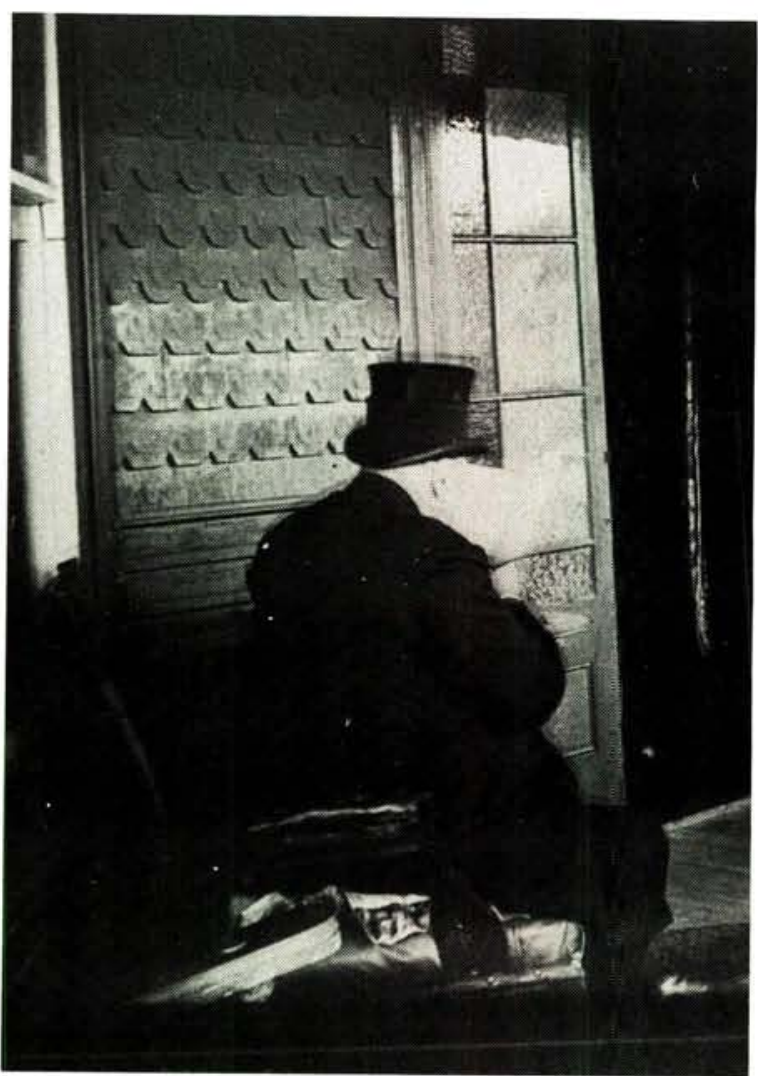

President S.J.P. Kruger op die stoep van die woning van goewerneur-generaal J.J. Machado, September-Oktober 1900. (Foto: Krugerhuismuseum, Pretoria) 


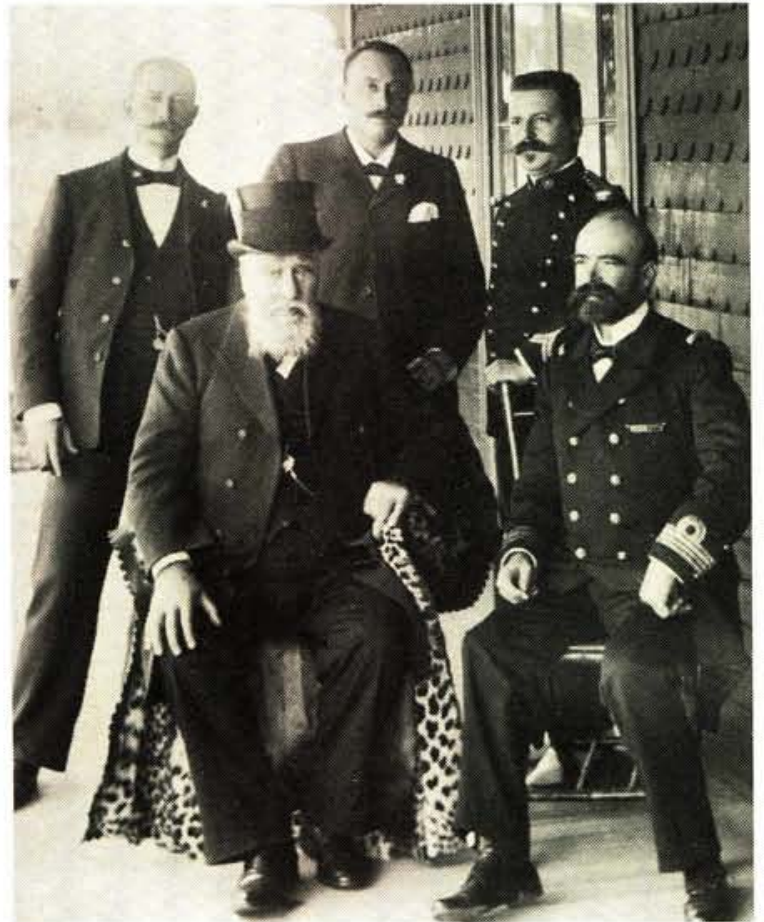

President S.J.P. Kruger en goewerneur-generaal J.J. Machado op die stoep van Machado se woning in Lourenco Marques. Agter staan (van links na regs): H.C. Bredell, dr. G.M.A. Heymans en die aide-de-camp van die Goewerneur-generaal. (Foto: Krugerhuismuseum, Pretoria)

Na sy vertrek uit Mosambiek was Machado in 1902 hoof van die sending wat die grens tussen Angola en Barotseland (in die huidige Zambië) vasgestel het. Op 5 Oktober 1908 is hy tot generaal bevorder. Die volgende jaar is hy as hoë kommissaris vir die grensafbakening van Macau aangewys. In 1910 is 'n republiek in Portugal uitgeroep en vier jaar later, op 7 Maart 1914, is Machado deur die nuwe regering weer eens as goewerneur-generaal van Mosambiek aangestel, 'n amp wat hy met groot onderskeiding beklee het. Hy het in 1919 afgetree, waarna hy hom veral op die werksaamhede van die Portugese Rooikruis toegespits het. Ten tyde van sy dood was hy dan ook die pesident van hierdie organisasie. ${ }^{12}$

Machado was ' $n$ ywerige ondersteuner van die Sociedade de Geografia, 'n geografiese genootskap wat in 1875 in Lissabon gestig is. Vanweë sy kennis van suidelike Afrika het hy dikwels oor dié wêrelddeel voordragte voor die genootskap gelewer. Drie daarvan is in 1881 onder die titel Moçambique gepubliseer, terwyl die Sociedade de Geografia in 1882 die publikasie $O$ Caminho de Ferro de Lourenço Marques, paracer da comissão africana e informaçao apresentada pelo vogal Joaquim José Machado uitgegee het, waarin Machado se aandeel in die aanlê van die spoorlyn benadruk word. Van Machado se referate is ook in die genootskap se Boletins opgeneem ${ }^{13}$

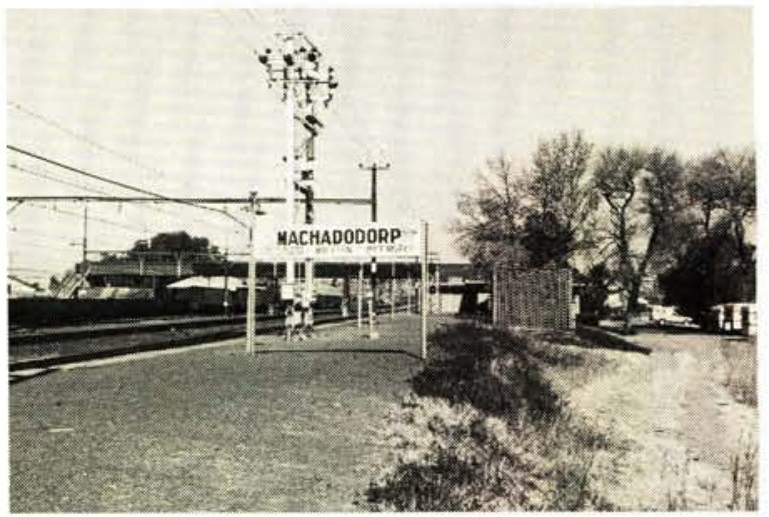

Die Stasie van Machadodorp, 1987. (Foto: O.J.O. Ferreira)

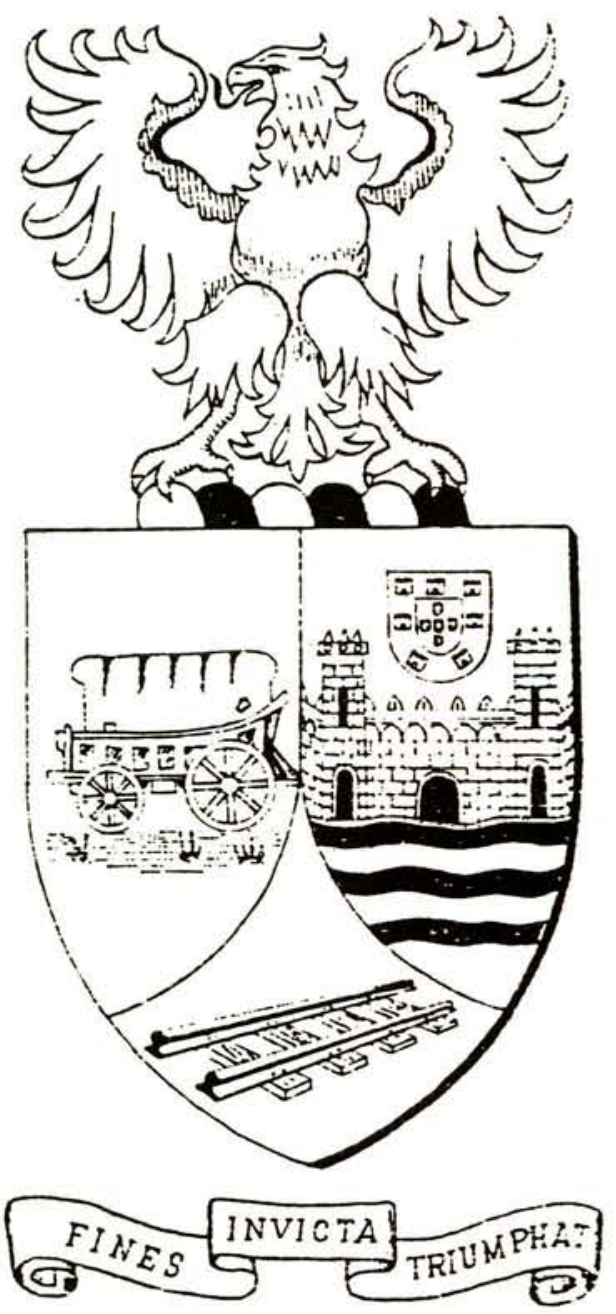

Dorpswapen van Machadodorp. Die arend, heraldiese simbool van gesag, dui op die periode toe Machadodorp die tydelike regeringsetel van die Z.A.R. was. Die wa is verteenwoordigend van die Transvaal en die Portugese staatswapen en Lagos se fort dui op generaal Machado se afkoms. Die spoorweg simboliseer die verbinding tussen Mosambiek en Transvaal. 
'n Drietal plekke in suidelike Afrika is na Machado vernoem. Soos reeds vermeld is 'n klein stasie langs die Oosterlyn in Oos-Transvaal in 1893 deur die regering van die Z.A.R. Machadodorp genoem as blyk van waardering vir Machado se verdienstelike werk in verband met die opmeting van die spoorlyn. Op die dorpswapen van Machadodorp, ontwerp deur die Portugese historikus A.P. de Lima, kom daar twee stukke voor wat 'n direkte verband met generaal Machado het, naamlik die staatswapen van Portugal en die fort van Lagos, die simbool van die geboorteplek van Machado. ${ }^{14}$ In die distrik Neves-Ferreira in Mosambiek, op die pad tussen Beira en Umtali, is daar 'n plekkie wat die naam Vila Machado dra. In Angola is die plekkie Canacupra tot Vila General Machado herdoop. In sy geboorteplek, Lagos, dra een van die strate sy naam. ' $n$ Monument tot sy gedagtenis is in Lobito, Angola, opgerig. ${ }^{15}$ Op die Pretoriase stasie is ' $n$ bronsplaat as gedenkteken vir Machado aangebring. Op die plaat verskyn 'n reliëfborsbeeld van Machado met daaronder ' $n$ teks in Portugees, Afrikaans en Engels, waarvan die Afrikaanse weergawe soos volg lui:

TER ERE VAN
GENERAAL JOAQUIM
JOSÉ MACHADO,
GENERAAL VAN DIE
INGENIEURSKORPS,
WAT GEDURENDE
1882-1884
BAANBREKERSWERK
VERRIG HET OP DIE
ROETE VIR DIE
SPOORLYN LOURENÇO
MARQUES-PRETORIA
WAT OP 8.7.1895
OOPGESTEL IS.

Hierdie plaat is op 14 Julie 1970 deur ingenieur F.A.S. Seixas, direkteur van die Caminhos de Ferro de Moçambique, onthul tydens die 75-jarige herdenking van die oopstelling van die Oosterlyn. ${ }^{16}$

Onder die talle onderskeidings wat Machado ontvang het, was die Portugese Orde van Santiago en die Orde van S. Bento d' Aviz (1901), asook die Britse Orde van St. Michael en St. George (1903). ${ }^{17}$

Machado is op 22 Februarie 1925 in sy huis in Estrada de Benfica 386 in Benfica, 'n voorstad van Lissabon, oorlede. Sy begrafnis is deur 'n groot aantal mense, waaronder die Portugese

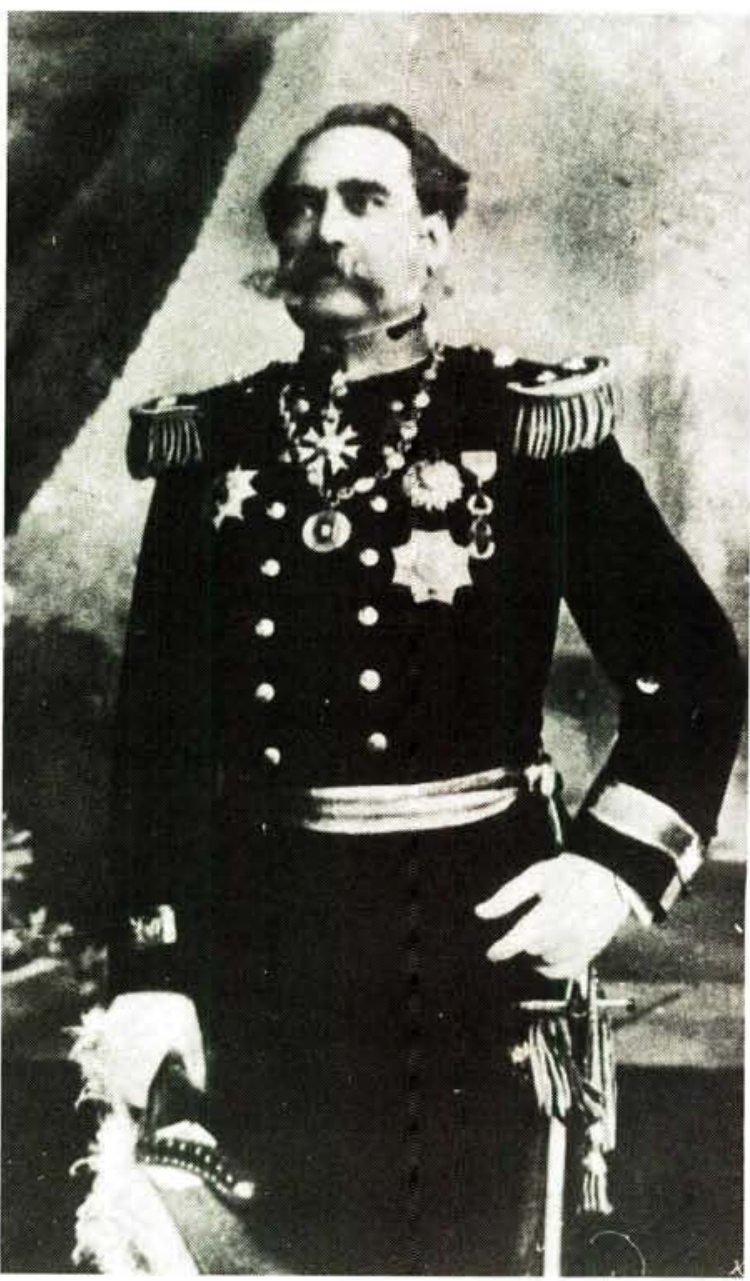

Generaal Joaquim José Machado tydens sy ampstermyn as goewerneur-generaal van Mosambiek. (Foto: Transvaalse Argiefbewaarplek, Pretoria)

Minister van Kolonies, bygewoon. Die lykwa met sy mahoniekis, bedek met die vlag van die Sociedade de Geografia, is deur ' $n$ span perde na die begraafplaas getrek. Lede van die Rooikruis het as slippedraers opgetree. Sy stoflike oorskot rus in die familiegraf in die Benfica-begraafplaas. Hy het sy eggenote, Mariana Cardoso de Melo, en drie kinders nagelaat. Die kinders was: Alvaro de Melo Machado, 'n vlootoffisier; Francisco de Melo Machado, 'n eiendomsbesitter; en Margarida de Melo Machado, die eggenote van Antonio José de Almeida Lima. ${ }^{18}$

Hoewel Machado se imposante gestalte en sy deurdringende blik die indruk gewek het dat hy 'n ongenaakbare mens was, was hy in werklikheid ' $n$ baie sensitiewe man. Binne sy eie familiekring het hy ' $n$ fyn humorsin openbaar. ${ }^{19}$ Sy intelligensie en hardwerkendheid het daarvoor gesorg dat die meeste ondernemings wat hy aangepak het met sukses bekroon is. Die voortreflike wyse waarop hy sy pligte in Mosambiek uitgevoer het, het die bewondering van sy kolle- 


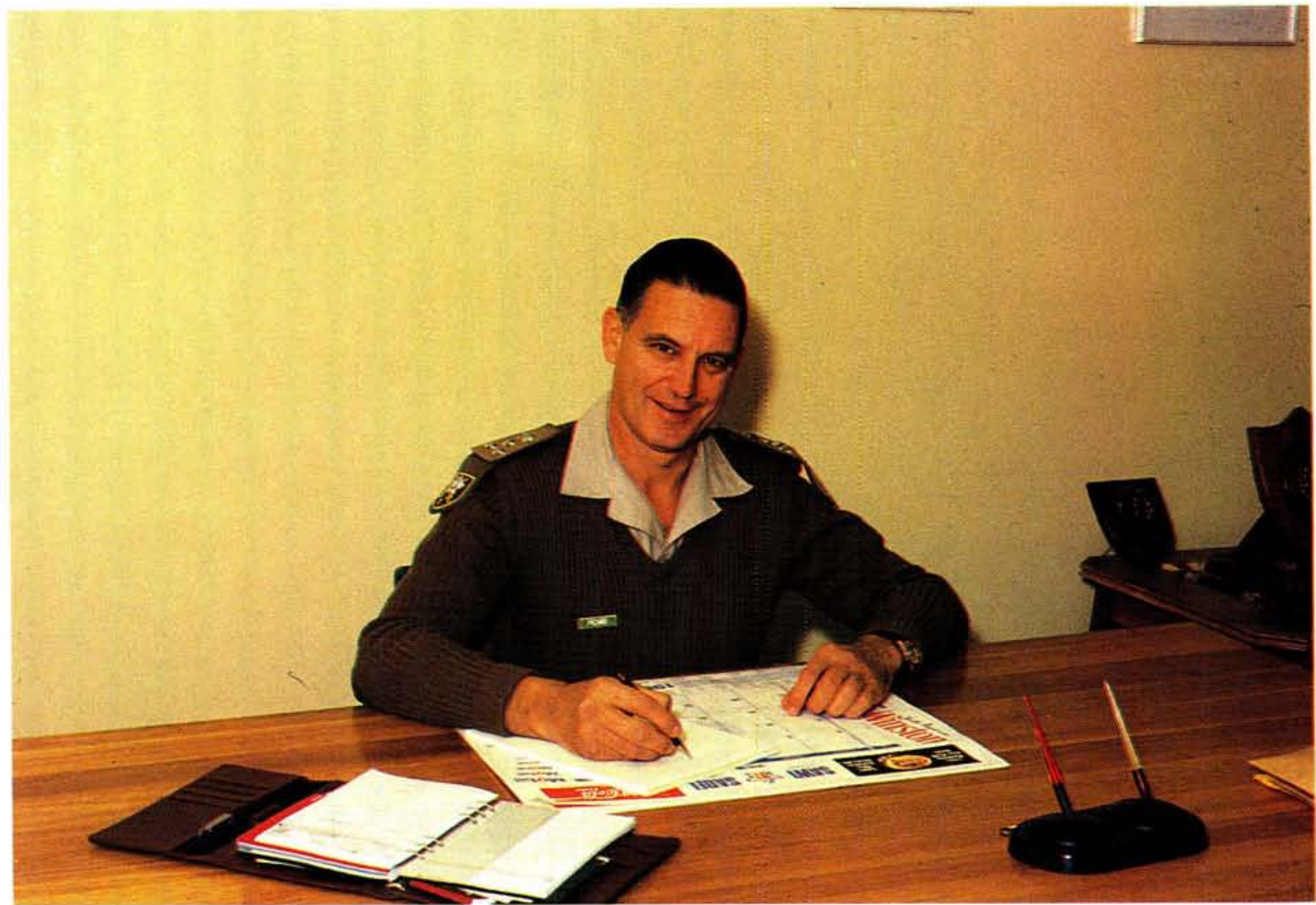

Brig. J.H. Picard, SM, Direkteur Taaldiens.

(Fotograaf: Sappeur Dirk v.d. Berg)

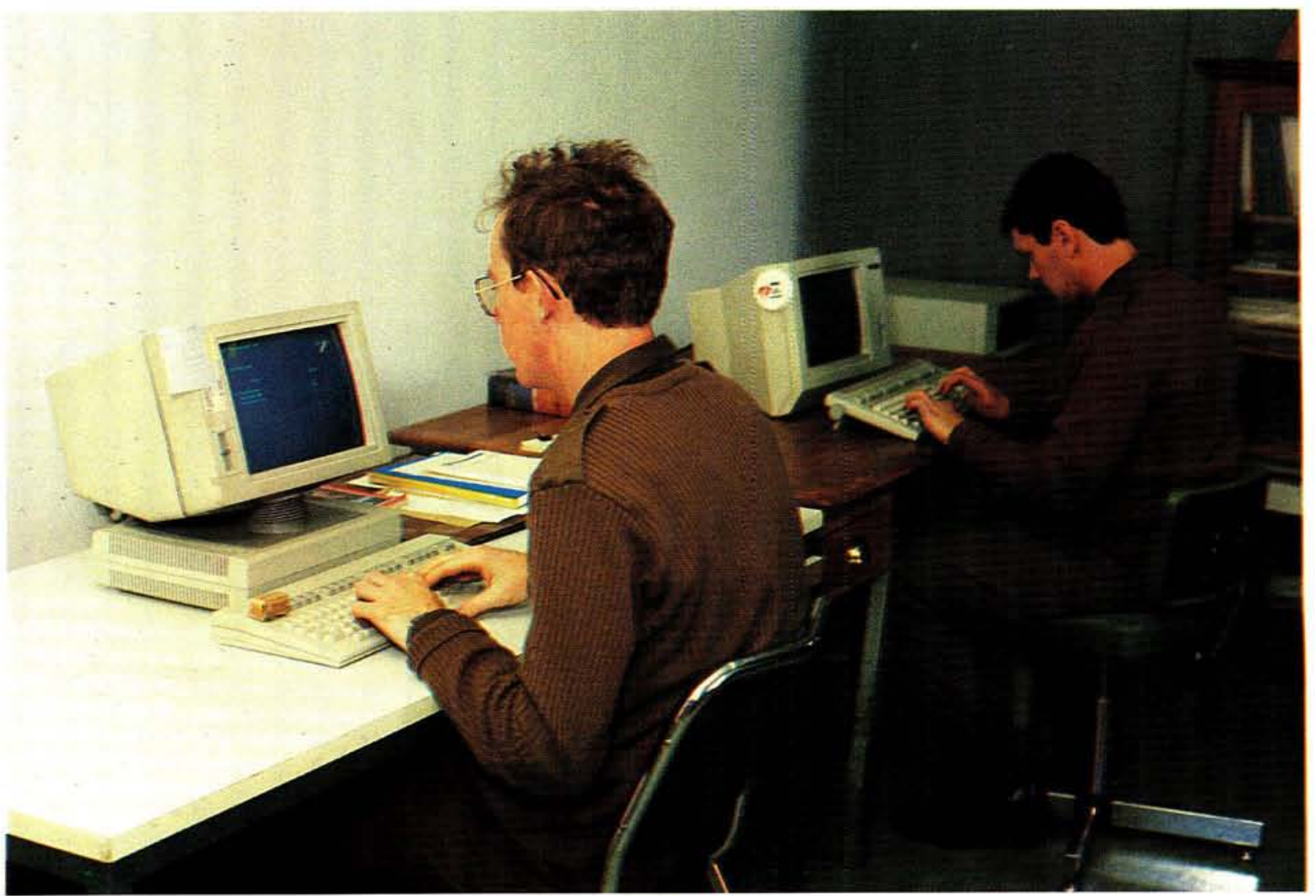

Die Terminologieseksie is gekoppel aan landwye en internasionale datanetwerke en die storing en herwinning van terminologie is slegs een van die aspekte wat hier gedek word.

(Fotograaf: Sappeur Dirk v.d. Berg) 


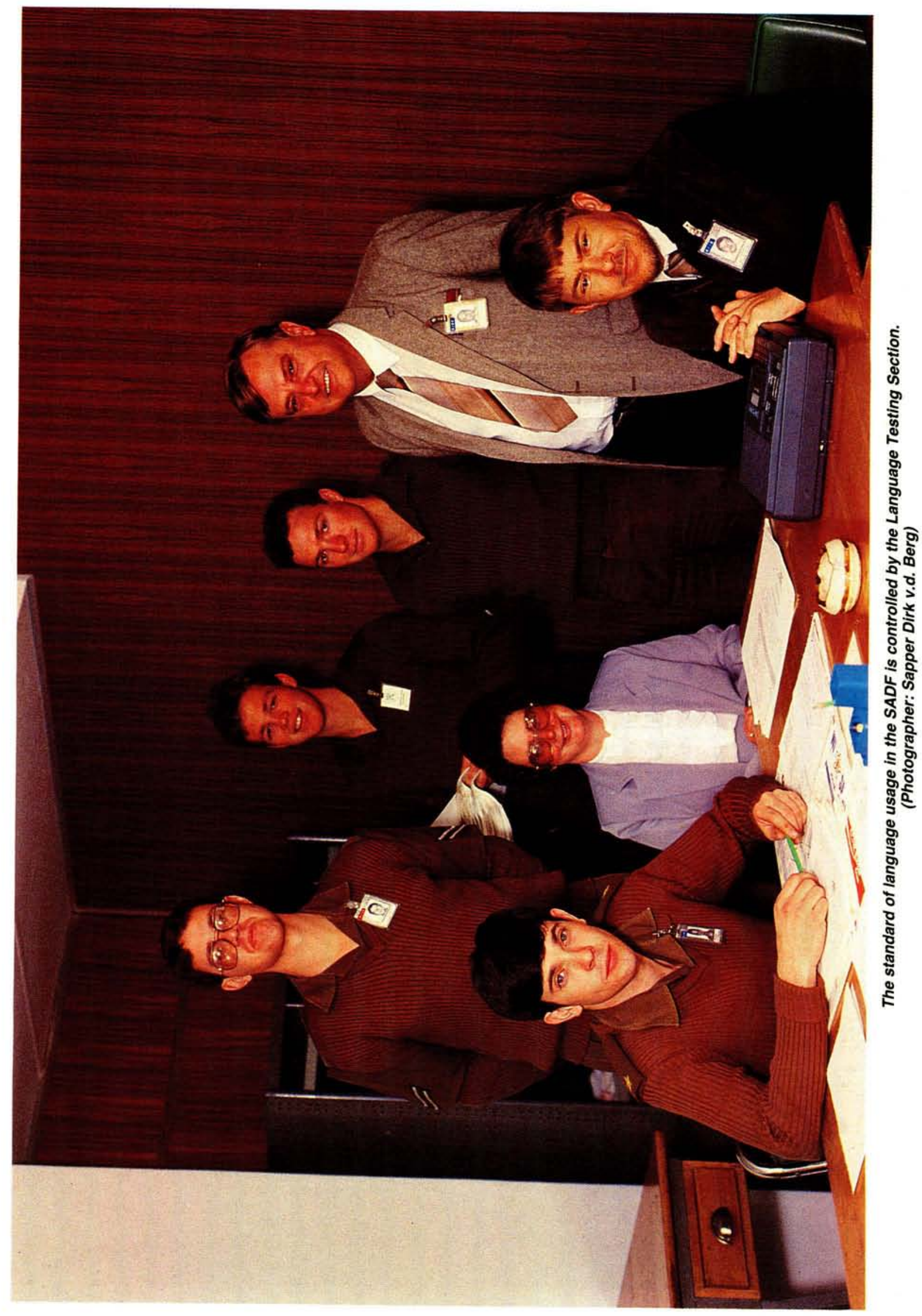


gas, die goewerneurs van Mosambiek en die Portugese regering afgedwing en dit het in verskeie verslae neerslag gevind. Veral die aanlê van die Delagoabaai-spoorlyn het tot die ekonomiese vooruitgang van Mosambiek bygedra. In suidelike Afrika, 'n gebied waarvoor Machado hartstogtelik lief was, sal sy naam altyd onafskeidbaar aan die geskiedenis van die spoorwegontwikkeling gekoppel bly.

* Prof. 0.J.0. Ferreira is verbonde aan die Dept. Afrikaanse en Nederlandse Kultuurgeskiedenis van die Universiteit van Pretoria.

\section{VOETNOTAS}

1. G. du Preez (red.). Geskiedenis van Machadodorp (S.p., 1952), pp. 6-3 en 15-16; H.J.M.P., 'Machadodorp', Die Brandwag 11(7), 1920.12.24, p. 182.

2. Du Preez. op. cit, pp. 10-12; 0 Hintrager, Geschichte von Südafrika (München, 1952), p. 365; D. van Niekerk, 'Paul Kruger se laaste hoofstad', in C. Barnard, Die Transvaalse Laeveld: kamee van 'n kontrei (Kaapstad, 1975), pp. 49-50; J.J. Oberholster, Die historiese monumente van Suid-Afrika (Kaapstad, 1972), p. 335

3. Diário de Notícias, 1925.02.22; H. Strelocke, Portugal: Vom Algarve zum Minho (Keulen, 1983), pp. 157-158; G.M. Graham en A. Israel, Portugal: Land of sunshine (Lissabon, 1971), p. 156.

4. Skrittelike mededeling: J. Almeida Lima, Amadora, Portugal, 1987.02.24; Diário de Notícias, 1925.02.22.

5. Grande Enciclopédia Portuguesa e Brasileiro XV (Lissabon/Rio de Janeiro, c. 1950), p. 761; Diário de Notícias, 1925.02.22.
6. Diário de Notícias, 1925.02.22; Grande Enciclopédia ... XV. p. 761; Arquivo Histórico Militar. Lissabun: Caixa 587 - Diensstaat van J.J. Machado.

7. Diário de Notícias, 1925.02.22; Grande Enciclopédia ... XV, p. 761; R. Musiker, Machado, Joaquim José, in D.J. Potgieter (red.), Standard Encyclopaedia of Southern Africa VII (Kaapstad, 1972), p. 92; J. Coetzee, 'Die Oosterspoor', in C. Barnard, Die Transvaalse Laeveld: kamee van 'n kontrei (Kaapstad, 1975), pp. 41-42.

8. D.J. Coetzee, Spoorwegontwikkeling in die Suid-Afrikaanse Republiek (1872-1899) (Kaapstad, 1940), pp. 32-33; Gedenkboek uitgegeven ter gelegenheid der feestelyke opening van den Delagoabaaispoorweg (Amsterdam, 1895), pp. 5-6 en 46-47; Diário de Notícias, 1925.02.22.

9. Grande Enciclopédia .... XV, p. 762; Diário de Notícias, 1925.02.22; Arquivo Histórico Militar, Lissabon: Caixa 587 - Diensstaat van J.J. Machado.

10. E. Axelson, Portugal and the scramble for Africa 1875-1891 (Johannesburg, 1967), p. 156; Diário de Notícias, 1925.02.22; Grande Enciclopédia ... XV, p. 762; Anoniem, 'Railway engineering in Mocambique', Railway Engineering 16(3), May-June 1972, p. 5.

11. D.W. Krüger, Paul Kruger II, 1883-1904 (Johannesburg, 1963), pp. 263-264; Paul Kruger, Gedenkskrifte van ... (reds. H.C. Bredell en P. Grobler) (Pretoria, 1947), pp. 177-178.

12. Arquivo Hlstórico Militar, Lissabon: Caixa 1549 en 1754 - Diensstaat van J.J. Machado; Diário de Notícias, 1925.02.22; Grande Enciclopédia XV. p. 762

13. Skrittelike mededeling: Direkteur, Arquivo Nacional da Torre do Tombo, Lissabon, 1986.08.08; Grande Enciclopédia ... XV, p. 762; Diário de Notícias, 1925.02.22.

14. Anoniem, 'Town debt to history', South African Railways and Harbours Magazine, April 1965, pp. 477-479; Du Preez, op. cit., p. 7.

15. Grande Enciclopédia ... XV, p. 762; D. Alexander, Holiday in Mozambique (Kaapstad, 1971), pp. 130-131.

16. Gedenkteken vir J.J. Machado, Pretoriase Stasie, Pretoria,

17. Arquivo Histórico Militar, Lissabon: Caixa 1549 - Diensstaat van J.J. Machado; Skriftelike mededeling: Henriette Nesbitt de Almeida Lima, Lissabon, 1986.05.14; Diário de Notícias, 1925.02.22.

18. Skriftelike mededeling: J. Almeida Lima, Amadora, Portugal, 1987.02.24; Diário de Notícias, 1925.02.22 en 1925.02.23.

19. Skriftelike mededeling: J. Almeida Lima, Amadora, Portugal, 1987.02.24. 